\title{
Performance Analysis and Implications of Operational Procedures Service Standard Guidelines for Internships and Research Paper
}

Fauzie Rahman, Fahrini Yulidasari, Meitria Syahadatina N, Dian Rosadi, Atikah Rahayu, Nur Laily and Hadianor H $^{*}$

Department of Public Health, Medical Faculty, Lambung Mangkurat University, Indonesia

*Corresponding author: Hadianor H, Departement of Public Health, Medical Faculty, Lambung Mangkurat University, Indonesia, Tel: +625113306694; E-mail: hadianor539@gmail.com

Received date: November 08, 2018; Accepted date: November 15, 2018; Published date: November 21, 2018

Copyright: (c) 2018 Rahman F, et al. This is an open-access article distributed under the terms of the Creative Commons Attribution License, which permits unrestricted use, distribution, and reproduction in any medium, provided the original author and source are credited.

\begin{abstract}
Objective: Study is to analyze the factors that influence the performance of lecturers in carrying out the teaching and learning process, especially in the internship and thesis programs in the Public Health Study Program, Faculty of Medicine, University of Lambung Mangkurat and efforts that must be made to improve lecturer performance and service in the guidance process to college student.
\end{abstract}

Sample: The sample in this study was taken from a total population of 30 permanent educators/lecturers.

Methods: The study also used the survey method with the aid of the questionnaire as the main instrument of data collection.

Results: The most age groups as scientific papers and Internship supervisors are the 30-37 year age group $(47.3 \%)$. The education of respondents who are mentors for internships and Eastern Indonesia is mostly educated S2 $(73.7 \%)$. The working period of the respondents who become the intern and guidance counselor as large is included in the old category $(78.9 \%)$. The perception of scientific papers guidance performance shown is the perception of performance in the good category $(100 \%)$. The perception of the performance of apprenticeship guidance shown is the perception of performance in the good category $(100 \%)$. Perceptions of motivation of respondents who become mentors for internships are all in the high category $(100 \%)$. The guiding satisfaction by the respondents is all in the category of feeling satisfied with the benefits received (100\%). Perception of scientific papers guidance supervision and internships all have good perceptions of scientific papers guidance and internships $(100 \%)$.

Keywords: Performance; Operational procedures service standard; Internship; Research paper

\section{Introduction}

The Bachelor of Public Health as a health worker is required to provide health messages in the form of activities of communication, information and education to the community so that it is expected to improve public welfare and health $[1,2]$. In an effort to produce high quality health services, the quality of health human resources needs to be improved through the development of quality educational institutions. One effort to improve the quality of educational institutions is through improving the performance of lecturers in carrying out the teaching and learning process [1]. The quality of educational institutions is strongly influenced by input to the education system including students, lecturers and facilities to support the teaching and learning process.

These three factors are interdependent and influence each other in creating a successful teaching and learning process [3]. The main factor causing the low quality of education is the condition of the teacher, namely his qualifications are not feasible or teaching is not in accordance with his field of expertise. Challenges related to the quality of educators include personal challenges, personal competencies and educator skills in carrying out their duties $[4,5]$.
Lecturer performance is measured based on the lecturer workload includes the main activities namely planning learning, carrying out the learning process, evaluating learning, guiding and training, conducting research, doing community service and performing additional tasks. Lecturer workload is commensurate with 12 semester credit units (SKS) and as many as 16 semester credit units (SKS) $[3,4]$.

The individual behavior of a lecturer in achieving what he does is influenced by individual factors, psychology and organization. The performance factors include experience, skills, age, sex, education, years of service, responsibility, job satisfaction, perception, motivation, leadership, rewards, supervision, working conditions [6].

Supervision is an effort of guidance and direction to increase passion and work performance. Based on the results of the study of Djuwita [7], it was suggested that the achievement motives had an effect of $42.96 \%$, on work productivity. Public Health Study Program is one of the study programs under the Faculty of Medicine, Lambung Mangkurat University with accreditation B. Seeing developments and changes that are more directed to the main competencies of a Bachelor of Public Health (SKM), it is very necessary to organize human resources as educators. Educators should have academic qualifications, namely a minimum of Masters Graduates according to their field of expertise [7]. The quality quality of SKM graduates is inseparable from the quality of the learning process through the performance of their lecturers. 
Citation: Rahman F, Yulidasari F, Syahadatina MN, Rosadi D, Rahayu A, et al. (2018) Performance Analysis and Implications of Operational Procedures Service Standard Guidelines for Internships and Research Paper. J Health Educ Res Dev 6: 284. doi: $10.4172 / 2380-5439.1000284$

Page 2 of 7

\section{Problem statement}

Based on preliminary studies conducted on Public Health Study Program students, it is known that the performance of internal lecturers with sufficient categories is $37.14 \%$, while the performance of external lecturers with sufficient categories is $58.34 \%$. Meanwhile, most of the $38.11 \%$ lecturers were considered still lacking coordination with students. Based on the results of evaluations conducted by the Study Program Quality Assurance Unit for all students who program Internship and Scientific Writing courses, it was found that most lecturers did not have much time to consult directly (75\%) and provide input on the contents of student writing, often there was a delay in the guidance process and the lecturers of most lecturers rarely gave enthusiasm to students to improve their abilities in the scientific writing process. Some lecturers did not provide feedback on the guidance process conducted to students. Therefore, it can be said that there are problems in the performance of lecturers in carrying out the teaching and learning process, especially in the apprenticeship and student thesis programs at the Public Health Study Program.

\section{Objectives of the study}

The general objective of this study is to analyze the factors that influence the performance of lecturers in carrying out the teaching and learning process, especially in the internship and thesis programs in the Public Health Study Program, Faculty of Medicine, University of Lambung Mangkurat and efforts that must be made to improve lecturer performance and service in the guidance process to college student.

The specific objectives in this study are as follows:

1. Know the description of the variables of age, education, years of service, work motivation, job satisfaction, perceived benefits, and perceptions of supervision and lecturer performance.

2. Knowing the extent of work motivation, job satisfaction, perceived benefits, and perception of supervision and performance of lecturers.

3. Analyzing efforts that must be made in improving the performance of lecturers.

4. Analyzing standard operational procedures that should be understood by lecturers and students in the implementation of the teaching and learning process, especially in the internship and thesis programs in the Public Health Study Program, Faculty of Medicine, University of Lambung Mangkurat.

5. Formulate operational standards for internship and thesis program guidance procedures in the Public Health Study Program, Faculty of Medicine, Lambung Mangkurat University.

\section{Literature Review}

\section{Understanding of performance}

Performance is the success of an employee in completing work. Basically what employees do?. Employee performance is what influences how much they contribute to the organization, which includes quantity and quality of output, the duration of the output, attendance in the workplace and cooperation. Performance refers to something related to the activities of doing work, in this case including the results achieved by the work. Performance (performance) refers to the level of achievement of the tasks that make up an employee's work. Performance reflects how well employees fulfill a job [8].

\section{Work motivation}

Motivation is defined as an employee's attitude towards a situation in his organization. Those who are positive about their work situation will show high work motivation and vice versa if they are negative about the work situation will show low work motivation. Work motivation is something that gives rise to enthusiasm or work motivation $[9,10]$. Jaeludin et al. based on the results of his research suggests that work motivation correlates at 0.663 to work productivity [11].

According to Porter et al. it will be very useful for a manager to understand the behavior of his employees in the organization, if they want to see the motivation of their employees in a system. The system's view of the motivation of employees as a comprehensive whole and as part of the direction and development of the organization [11].

\section{Job satisfaction}

Job satisfaction is an individual thing. Each individual will have a different level of satisfaction according to the system of values that apply to him. This is due to differences in each individual. The more aspects in the work that are in accordance with the wishes of the individual, the higher the level of satisfaction he feels and vice versa [9].

According to Hoppeck, job satisfaction is an assessment of workers, namely how far the overall work satisfies their needs. Tiffin argues that job satisfaction is closely related to the attitude of employees to the work itself, work situations, cooperation between leaders and fellow employees. Blum argues that job satisfaction is a general attitude which is the result of some special attitudes towards work factors, selfadjustment and individual social relations outside of work [9].

Many people argue that salary or wages are the main factors for the emergence of job satisfaction. To a certain extent this is indeed acceptable, especially in a developing country where money is a vital need to be able to fulfill basic daily needs. However, if the community is able to meet their family's needs fairly, then this salary or wage is not the main factor. Watson believes that by providing a high enough salary, it is not certain to guarantee job satisfaction for employees. So wages or wages are not the only factor that can lead to satisfaction for someone, as Herzberg mentioned with the Two factor theory, it turns out that salaries or wages are included in groups that are dissatisfies.

\section{Education and teaching and learning}

Education: The definition of education according to the Republic of Indonesia Law No. 20 of 2005 concerning the national education system is a conscious and planned effort to create a learning atmosphere and learning process so that students actively develop their potential to have religious spiritual power, self-control, personality, intelligence, morals nobility and skills needed by him, society, nation and state $[12,13]$.

The success of the education system depends on the functional interaction of the sub-subsystem as a whole, known as the education process. Learning is the process of interaction of students with educators and learning resources in a learning environment [2]. Inputs for the education system include students, lecturers and facilities and 
Citation: Rahman F, Yulidasari F, Syahadatina MN, Rosadi D, Rahayu A, et al. (2018) Performance Analysis and Implications of Operational Procedures Service Standard Guidelines for Internships and Research Paper. J Health Educ Res Dev 6: 284. doi: $10.4172 / 2380-5439.1000284$

Page 3 of 7

facilities that support the implementation of the teaching and learning process.

\section{Teaching and learning process}

The teaching and learning process is a process that contains a series of actions of educators and students on reciprocal relationships that take place in educational situations to achieve certain goals. Interactions or reciprocal relationships between lecturers and students/ students are the main requirements for the learning process to take place [2].

The process in the sense here is the interaction of all components or elements contained in teaching and learning with each other interdependent in the bond to achieve goals. Which is included in the components of teaching and learning include instructional goals to be achieved in planning learning, subject matter, teaching methods and teaching aids used in the implementation of learning (teaching and learning process) and evaluation as a benchmark for achieving or not achieving goals [2]. In the teaching and learning process, lecturers as instructors will use guidelines in the curriculum in carrying out their duties. Through the teaching and learning process there is the delivery of information and knowledge as well as the planting of values and attitudes. At the end of an educational process, especially for higher education graduates will be obtained (output) who can develop and disseminate knowledge [3].

\section{Tasks, roles and competencies of educators/ lecturers}

Lecturers are professional educators and scientists with the main task of transforming, developing and disseminating science, technology and art through education, research and community service [14]. Qualifications of the lecturer academy are obtained through higher education in an accredited postgraduate program in accordance with the field of expertise. Lecturers have a minimum academic qualification of graduates of master's programs for diploma programs or undergraduate programs and graduate doctoral programs for postgraduate programs [14]. According to Djuwita based on the results of his research, it was suggested that the lecturer development strategy and achievement motives had a positive effect on lecturer productivity. Lecturer workload includes the main activities, namely planning learning, carrying out the learning process, carrying out evaluation of learning, guiding and training, conducting research, carrying out additional tasks and doing community service. The workload is at least commensurate with $12-16$ credits $[15,16]$.

\section{Task of educators/ lecturers}

Tasks as a profession include educating, teaching, and training. Educating means continuing and developing life-value values. While the role of Educators/Lecturers. The role and competence of the educator/lecturer in the teaching and learning process, includes many things, such as the arguments by Adam and Decay in the Principles Student Teaching, including teaching, leaders, mentors, environmental regulators, participants, expeditors, planners, supervisors, motivators and counselors [17].

\section{Internship program}

Internships are one of the compulsory courses for public health study program students at FK UNLAM, containing the substance of work practices in both government and private institutions that aim to provide work experience in certain fields relating to student expertise plans. By matching the three aspects of learning, namely cognitive, affective and psychomotor, the existence of an internship is expected to be able to complement or comprehend the theoretical knowledge that students have acquired during lectures with practice in the field, so that students will open their horizons to the development of expected skills and competencies.

Expectations desired by the public health study program of the Faculty of Medicine, University of Lambung Mangkurat in this internship program is to increase the ability of students to identify and solve problems related to work programs of the apprenticeship agencies, especially health programs with a public health-based management approach to the location of internship students. In addition, students are able to provide useful input for the improvement of existing programs at the institution.

In the implementation of internships in the field students are active and act as labor/employees in accordance with the field of expertise they have at the apprenticeship institution, so that students must follow all rules or regulations that apply to the place of internship. In essence, students identify health problems. Then the problems identified were attempted to provide suggestions for solutions which were subsequently set forth in the form of reports and disseminated at the public health study program-Faculty of Medicine, Lambung Mangkurat University at the end of the activity. In the whole series of internships, students will be guided by a supervisor.

Supervisor has the task:

1. Conducting guidance and coordination processes to students who carry out internships from the beginning to the completion of the internship;

2. Conduct regular supervision and evaluation to intern students during the internship process;

3. Helping all the difficulties experienced by student interns during the internship process;

4. Provide guidance and direction in the process of completing the apprenticeship report.

\section{Thesis program}

Thesis is an independent scientific work that must be carried out by public health study program students from the Faculty of Medicine, Lambung Mangkurat University to fulfill some of the requirements to obtain a Bachelor degree in Lambung Mangkurat University. Thesis has the same position with other courses, but different forms, teaching and learning processes and how to evaluate them. Thesis is given a weight of 4 credits programmed in 1 semester, equivalent to academic activities every week 4-5 hours per credits for one semester. Thesis is a final assignment, taking into account the limitations of time and the ability of students to conduct research. The research that underlies thesis writing can be in the form of basic public health research or applied research which is mainly based on the field of student intellectual interest. The purpose of thesis writing for students is:

\section{Comprehensive experience of scientific thinking.}

2. Conduct an analysis of the main problems that will be the topic of the research that will be conducted.

3. Conduct a search of the literature relevant to the problem under study. 
Citation: Rahman F, Yulidasari F, Syahadatina MN, Rosadi D, Rahayu A, et al. (2018) Performance Analysis and Implications of Operational Procedures Service Standard Guidelines for Internships and Research Paper. J Health Educ Res Dev 6: 284. doi: $10.4172 / 2380-5439.1000284$

Page 4 of 7

4. Applying research methods correctly and in accordance with applicable rules.

5. Analyze and interpret the data found, both primary and secondary data and report well according to the results obtained.

6. Compile and write the overall thesis, in accordance with the field of science that it occupies, based on scientific rules carried out by the students themselves.

7. Provide input and knowledge for parties directly related to research.

\section{Methods}

This type of research is observational with analytical descriptive. The population in this study was all permanent educators/lecturers of the Public Health Study Program of the Faculty of Medicine, University of Lambung Mangkurat. The sample in this study was taken from a total population of 30 permanent educators/lecturers in the Public Health Study Program me. The instrument that will be used in this study is a questionnaire/questionnaire used to assess the performance of lecturers in the teaching and learning process, age, education, years of service, work motivation, job satisfaction, perception of reward and perception of supervision.

The variables in the study were Age, Education, Work Period, Work Motivation, Job Satisfaction, Perception of Benefits and Perception Supervision. The indicators of performance assessment are assessments in carrying out the teaching and learning process. Performance is defined as the success of the respondent in completing work with the object of assessment in the process of carrying out the teaching and learning process which includes planning, implementation and evaluation. Age is defined by the age of the respondent by being measured based on the number of years, if age $\geq 0.5$ is rounded up and if $<0.5$ is rounded down. Education is defined as the education level of the respondent based on the level of education of Master or Bachelor/ Diploma IV/ Diploma III. The working period is defined as the length of work of the respondent since becoming a civil servant up to the time of conducting the PBM. Motivation is defined as the impulse that arises in the respondent's self to carry out the teaching and learning process which includes encouragement to guidance responsibilities, student achievement, rewards and self-actualization in coaching. Job satisfaction is defined as the suitability of what is expected with the reality experienced by respondents in carrying out the teaching and learning process. Reward perception is defined as the respondent's perception of all forms of financial rewards (salary, honorarium, incentives). Perception of supervision is the perception of the lecturer on the implementation of supervision activities (coaching, guidance, direction and supervision) of the head of the study program on the implementation of the teaching and learning process.

\section{Results}

\section{Characteristics of KTI advisors and internships}

\begin{tabular}{|l|l|l|}
\hline Category & Frequency & Percent \\
\hline Young (<30 Year) & 5 & 26.3 \\
\hline Old ( $\geq 30$ Year) & 14 & 73.7 \\
\hline
\end{tabular}

\begin{tabular}{|l|l|l|}
\hline Total & 19 & 100 \\
\hline
\end{tabular}

Table 1: Age Frequency Distribution by Category.

Based on the results of the research in Table 1, it can be seen the frequency distribution of respondents' age from 19 respondents in the youngest age group is the age group $22-29$ years $(26.3 \%)$ and the most mature age is the age group $\geq 46$ years $(5.3 \%)$. Then the most age group of respondents is the $30-37$ year age group (47.3\%). From several age groups in Table 1, it can be categorized into 2 categories. Based on Table 2, it can be seen that the frequency distribution of respondents is more at the age of $\geq 30$ years $(73.7 \%)$. That age can be stated as an adult. Adult age can be said to be productive age. This is because productive age is a population whose age is capable of producing a product or service. The more a person's age increases the more information that can be absorbed so that information can become maturity in thinking. In addition, the increasing age of a person will have an impact on work [18-22].

\begin{tabular}{|l|l|l|}
\hline Education & Frequency & Percent \\
\hline Master & 16 & 84.2 \\
\hline Doctorate & 3 & 15.8 \\
\hline Total & 19 & 100 \\
\hline
\end{tabular}

Table 2: Education Frequency Distribution.

Based on the results of the study (Table 2), it can be seen that the frequency distribution of the highest education level of the respondents is Master (84.2\%). Education is the level or strata of the school that has been achieved by individuals with the final result of getting a diploma. If the education is high, it will be more open to insight and strive to renew the knowledge and quickly adjust to existing reforms. According to Notoatmodjo [22], education in individuals/groups aims to seek the expected improvement in capacity.

\begin{tabular}{|l|l|l|}
\hline Years of service & Frequency & Percent \\
\hline New ( $\leq 3$ Year) & 4 & 21.1 \\
\hline Long $(>3$ Year) & 15 & 78.9 \\
\hline Total & 19 & 100 \\
\hline
\end{tabular}

Based on the results of the study (Table 3), it can be seen the frequency distribution of the working period of 19 respondents, with a (78.9\%). Based on the results of the study, it can be seen that the respondent's tenure based on the theory can be stated that the respondents are included in the long service period. The length of a person's work in a field of expertise will have an impact on performance. This is because the longer a person works on a job; the more experienced that skill will be, so that it can improve the achievement of its capacity as a teaching staff [22].

\begin{tabular}{|l|l|l|}
\hline Category & Frequency & Percent \\
\hline Less & 0 & 0 \\
\hline Well & 19 & 100 \\
\hline
\end{tabular}

Table 3: Education Frequency Distribution. new service period $(21.1 \%)$. While the length of service of respondents 
Citation: Rahman F, Yulidasari F, Syahadatina MN, Rosadi D, Rahayu A, et al. (2018) Performance Analysis and Implications of Operational Procedures Service Standard Guidelines for Internships and Research Paper. J Health Educ Res Dev 6: 284. doi: $10.4172 / 2380-5439.1000284$

Page 5 of 7

Total 19

100

Table 4: Distribution Perception of Performance of Scientific Writing Advisors.

Based on the results of the study (Table 4), it can be seen the frequency distribution of respondents' perceptions of performance. From 19 respondents, the perception of performance shown was the perception of performance in a good category (100\%) which means that the perceptions of respondents to their work in scientific writing guidance services are still in good condition. According to Mangkunegara, performance is the result of work both in quality and quantity that workers achieve in carrying out their duties in accordance with their responsibilities [23,24].

\begin{tabular}{|l|l|l|}
\hline Category & Frequency & Percent \\
\hline Less & 0 & 0 \\
\hline Well & 19 & 100 \\
\hline Total & 19 & 100 \\
\hline
\end{tabular}

Table 5: Frequency Distribution of Performance Perception of Internship Advisors.

Based on the results of the study (Table 5), it can be seen the frequency distribution of respondents 'performance perceptions from 19 respondents, perceptions of performance shown are perceptions of performance in good categories (100\%) which means that respondents' perceptions of their work in scientific writing guidance services are still in good condition. According to Mangkunegara, performance is the result of work both in quality and quantity that workers achieve in carrying out their duties in accordance with their responsibilities [25].

\begin{tabular}{|l|l|l|}
\hline Motivation & Frequency & Percent \\
\hline Low & 0 & 0 \\
\hline High & 19 & 100 \\
\hline Total & 19 & 100 \\
\hline
\end{tabular}

Table 6: Frequency Distribution Perception of Work Motivation of Respondents.

Based on the results of the study (Table 6), it is known that the frequency distribution of respondents' perception of work motivation is high (100\%). work motivation experienced by respondents is still high. This can be seen from the number of respondents' assessment results of $94.7 \%$ in statements number 5 and 7 where the statement is accompanied by statements that represent motivation from inside and outside. This of course will lead to someone's performance. The higher the perception of motivation the higher the performance of a person [25].

\begin{tabular}{|l|l|l|}
\hline Category & Frequency & Percent \\
\hline Less satisfactory & 0 & 0 \\
\hline Satisfy & 19 & 100 \\
\hline
\end{tabular}

\begin{tabular}{|l|l|l|}
\hline Total & 19 & 100 \\
\hline
\end{tabular}

Table 7: Frequency Distribution of Respondents' Rewards Perception Categories.

Based on the results of the study (Table 7), it can be seen that the frequency distribution of rewards received by respondents was 19 respondents, with satisfaction with the rewards received as many as 19 respondents (100\%). Rewards are one of the motivations for someone to run a job. Rewards obtained in the form of money/salary, work promotion and other awards given are in accordance with their performance. The results of the above research can be seen that respondents feel satisfied with the benefits received (100\%). These results corroborate the theory of Timpe et al. which explains that rewards are one of the important factors that can affect performance, because rewards are a reflection of the measure of employee performance values [25-28].

\begin{tabular}{|l|l|l|}
\hline Category & Frequency & Percent \\
\hline Less & 19 & 100 \\
\hline Well & 19 & 100 \\
\hline Total & 57 & 100 \\
\hline
\end{tabular}

Table 8: Frequency Distribution Perception Category Supervision.

Based on the results of the study (Table 8), it can be seen the frequency distribution of lecturer supervision from 19 respondents in all with good results (100\%). Respondents' answers are known to tend to assess the supervision carried out by supervisors in this case is the scientific writing unit and the apprenticeship and the study program executive unit are good. The implementing unit is able to direct the respondent before carrying out his duties as a supervisor. The implementing unit provides an opportunity for lecturers to express their opinions and provide guidance to all existing lecturers.

\section{SOP for internship guidance and scientific writing}

Internship guidance procedure: In the apprenticeship guiding process, an SOP must be made which becomes a reference or guideline for both the mentor and student in carrying out the internship process as well as compiling the results of the apprenticeship activity report. The details of the procedures in apprenticeship coaching are as follows:

1. Students who have registered as participants in the internship course must consult with a designated supervisor.

2. Guidance schedule is determined by students and their supervisor. Minimum guidance is five times per supervisor.

3. Every time you give guidance, students must bring an internship consultation book to ask for their supervisor's signature.

4. Students who do not conduct guidance within a specified time for three consecutive times without acceptable reasons will be given a written warning by the Study Program UP intern coordinator. If after the first two weeks the warning is not heeded, a second warning is issued. If after two weeks the second warning is not heeded, a third warning is issued. If after the third week of the third warning is not heeded, the supervising lecturer has the right to raise objections in writing and return his coaching duties to the Internship UP Coordinator. 
Citation: Rahman F, Yulidasari F, Syahadatina MN, Rosadi D, Rahayu A, et al. (2018) Performance Analysis and Implications of Operational Procedures Service Standard Guidelines for Internships and Research Paper. J Health Educ Res Dev 6: 284. doi: $10.4172 / 2380-5439.1000284$

Page 6 of 7

5. If within one semester the student cannot show the progress of the apprenticeship report, the faculty has the right to hold an evaluation. Apprenticeship guidance is said to not keep up the coaching time if:

a. Three times in a row do not keep the agreed coaching time and do not replace it without justifiable reasons.

b. Get a special assignment from of the Faculty of Medicine, University of Lambung Mangkurat for at least three months continuously which does not allow guidance without returning the guidance task to the faculty.

\section{Procedure for guidance for writing scientific writing}

1. Students who have registered as Thesis subject takers must consult with a designated supervisor.

2. Guidance schedule is determined by students and their supervisor. Minimum guidance is five times per semester per supervisor.

3. Every time you give guidance, students must bring a thesis consultation book to ask for their supervisor's signature.

4. Students who do not conduct guidance within a specified time for three consecutive times without acceptable reasons will be given a written warning by the UP-P2M and Thesis coordinator of the Study Program. If after the first two weeks the warning is not heeded, a second warning is issued. If after two weeks the second warning is not heeded, a third warning is issued. If after the third week of warning is not heeded, the supervising lecturer has the right to submit objections in writing and return his guidance task to the Chairperson of UP-P2M and Thesis.

5. If within one semester the student cannot show the progress of his thesis, the faculty has the right to hold an evaluation. Thesis guidance is said to not keep up the coaching time if:

a. Three times in a row do not keep the agreed coaching time and do not replace it without justifiable reasons.

b. Get a special assignment from the Faculty of Medicine, University of Lambung Mangkurat for at least three months continuously which does not allow for guidance without returning the guidance task to the faculty.

\section{Conclusion}

1. The most age groups as scientific papers and Internship supervisors are the 30-37 year age group (47.3\%).

2. The education of respondents who are mentors for internships and Eastern Indonesia is mostly educated S2 (73.7\%).

3. The working period of the respondents who become the intern and guidance counselor as large is included in the old category (78.9\%).

4. The perception of scientific papers guidance performance shown is the perception of performance in the good category (100\%).

5. The perception of the performance of apprenticeship guidance shown is the perception of performance in the good category (100\%).

6. Perceptions of motivation of respondents who become mentors for internships are all in the high category (100\%).
7. The guiding satisfaction by the respondents is all in the category of feeling satisfied with the benefits received (100\%).

8. Perception of scientific papers guidance supervision and internships all have good perceptions of scientific papers guidance and internships (100\%).

\section{Recommendation}

It is expected that with this study the output of an SOP for the implementation of scientific papers guidance and the internship can be applied to the SOP in providing guidance to students so that the implementation of scientific papers preparation and internships by students becomes even better.

\section{References}

1. Association of Public Health Higher Education Institutions (2014) Academic Script for Public Health Higher Education.

2. FK UNLAM Public Health Study Program (2016) Academic Guidebook for 2016.

3. Anonymous (2005) Law No. 14 Teacher and Lecturer. Focusmedia. Bandung.

4. Djohar H (2006) Education and Coaching. Gravika Indah, Yoyakarta.

5. Ministry of Health (2003) Teachers in Indonesia: Education, Training and Struggle. Jakarta.

6. Mahmudi M (2005) Public Sector Performance Management, Academy of Management for YKPN Companies. Yogyakarta.

7. Djuwita TM (2004) Effect of Higher Education Lecturer Development Strategies and Achievement Motives on Productivity of Work, West Java.

8. Ratnawati Y (2002) Motivation Key Factors to Improve Organizational Performance. Jogjakarta Polytechnic Journal 1: 1-6.

9. Mathis RL, Jackson JH (2017) Management of Human Resources, PT. Salemba Emban Patria, Jakarta.

10. Suhat S (2006) Analysis of Influential Factors on Lecturer Performance in Implementing the Teaching and Learning Process at STIKES Mahardika Cirebpn Academic Year 2005/2006.

11. Assad M (2004) Industrial Psychology, Liberty, Yogyakarta.

12. Mangkunegara AP (2006) HR Performance Evaluation, Refika Aditama, Bandung.

13. Jaeludin S (2005) Teacher's Perception Contribution About Career Development and Work Motivation on Productivity Works.

14. Siagian SP (2003) Human Resources Management. Earth Literacy. Jakarta.

15. Depdiknas D (2001) Education as a system. Director General of Higher Education. Jakarta.

16. National Education System (2005) Set of Regulations Per Law-Teacher and Lecturer Invitations. Fokusmedia. Bandung.

17. Djuwita TM (2004) Effect of Higher Education Lecturer Development Strategies and Achievement Motives on Productivity of Work, West Java.

18. Usman MU (2006) Become a Professional Teacher, Teenager Rosida Karya, Bandung.

19. Sukmadinoto NS (2005) The Foundation of Educational Process Psychology, Youth Rosida Karya. Bandung.

20. Central Bureau of Statistics (2014) Statistics of Indonesian youth in 2014.

21. Kreitner R, Kinicki A (2002) Organizational Behaviour. 2nd edn., McGraw Hill, London, pp: 206-220.

22. Notoatmodjo S (1993) Introduction to health education and behavioral science. Yogyakarta: Andi Offset.

23. Gibson JL, Ivancevich JM, Donnely JH (1996) Organization: Behavior structure and process. Translation by Adiami N. Jakarta: Bina Rupa Aksara. 
Citation: Rahman F, Yulidasari F, Syahadatina MN, Rosadi D, Rahayu A, et al. (2018) Performance Analysis and Implications of Operational Procedures Service Standard Guidelines for Internships and Research Paper. J Health Educ Res Dev 6: 284. doi: $10.4172 / 2380-5439.1000284$

Page 7 of 7

24. Mangkunegara AP (2011) Company human resource management. 10th edn., Bandung: Teenager Rosdakarya.

25. Cushway B (1996) Human resouces management. Jakarta: Elex Media Komputindo.

26. Rivai V (2005) Human Resource Management for Companies. Raja Gravindo, Jakarta.
27. Sutrisno (2009) Human Resource Management. Jakarta: Kencana.

28. Muchlas M (2005) Organizational Behavior 1: Organizational behavior. Yogyakarta: Postgraduate Masters in Management Education Program. 